Islam, M. S., Khan, A. A., Rubayet, M. T., Haque, M. M., Karim, M. A., Mian, I. H. (2021): Effect of magnesium and sulfur fertilizer on yield, diseases and disorders of seed potato. Agriculture and Forestry, 67(1): 239-254

DOI: 10.17707/AgricultForest.67.1.20

Mohammad Saidul ISLAM ${ }^{1}$, Abu Ashraf KHAN ${ }^{2}$, M. Tanbir RUBAYET ${ }^{2}$, M. Moynul HAQUE ${ }^{3}$, M. Abdul KARIM ${ }^{3}$, Ismail Hossain MIAN ${ }^{2}$

\title{
EFFECT OF MAGNESIUM AND SULFUR FERTILIZER ON YIELD, DISEASES AND DISORDERS OF SEED POTATO
}

\begin{abstract}
SUMMARY
A study was undertaken to find out the effects of two major nutrient elements such as Magnesium $(\mathrm{Mg})$ and Sulfur $(\mathrm{S})$ on plant growth, tuber, and tuber disease incidence of potato (Solanum tuberosum L.). Data were recorded on stem number/ten hills, plant height, canopy coverage, tuber number per ten plants, tuber weight per plot and incidence of diseases such as common scab (Streptomyces scabis), dry rot (Fusarium sp.) and soft rot (Erwinia carotovora) of potato. The doses of nutrients were $\mathrm{Mg} @ 0,10,15,20 \mathrm{kgha}^{-1}$ and $\mathrm{S} @ 0,10,20$, $30 \mathrm{kgha}^{-1}$. Every nutrient increased plant growth and tuber yield but decreased disease incidence considerably over control up to second highest dosage. The highest yield of 33.61 and 31.50 tha $^{-1}$ were obtained with $15 \mathrm{kgha}^{-1} \mathrm{Mg}$ and 20 $\mathrm{kgha}^{-1} \mathrm{~S}$. When the two elements were applied together at $15 \mathrm{kgha}^{-1} \mathrm{Mg}$ and 20 $\mathrm{kgha}^{-1} \mathrm{~S}$ independently, the highest tuber yield of $35.48 \mathrm{tha}^{-1}$, and the incidence of tuber diseases and disorders were also minimal. Based on findings of the present study it may be concluded that application of $\mathrm{Mg}, 21.11 \mathrm{~kg}$ and $\mathrm{S}, 4.28 \mathrm{kgha}^{-1}$ along with $140 \mathrm{~kg} \mathrm{~N} \mathrm{ha}^{-1}$ are optimum for maximum plant growth, tuber yield and minimize incidence of disease and disorders of potato tuber.
\end{abstract}

Keywords: Magnesium, sulfur, potato, yield, quality.

\section{INTRODUCTION}

Potato (Solanum tuberosum L.) is one of the most widely cultivated horticultural crops in the world and holds the $4^{\text {th }}$ largest crop by global production volume (Marcomini et al., 2019). Now, it is cultivated and consumed more than

\footnotetext{
${ }^{1}$ Mohammad Saidul Islam, Senior Assistant Director, Seed Marketing, Bangladesh Agricultural Development Corporation, Gazipur, BANGLADESH.

${ }^{2} \mathrm{Abu}$ Ashraf Khan, M. Tanbir Rubayet (Corresponding author: tanbir86plp@gmail.com), Ismail Hossain Mian, Department of Plant Pathology, Bangabandhu Sheikh Mujibur Rahman Agricultural University, Gazipur, BANGLADESH.

${ }^{3}$ M. Moynul Haque, M. Abdul Karim, Department of Agronomy, Bangabandhu Sheikh Mujibur Rahman Agricultural University, Gazipur, BANGLADESH.

Notes: The authors declare that they have no conflicts of interest. Authorship Form signed online. Recieved:0707/2020 
160 countries worldwide (Andre et al., 2014). On the other hand, it ranks next to rice and wheat in terms of production and internal demand in Bangladesh (Rubayet et al., 2017). It contains significant amount of Vitamin-B, C and minerals. The yield of the crop in Bangladesh is very low compared to other potato growing counties. The average yield of potato in Bangladesh is 19.6 tha $^{-1}$ in 2014-15 which is much below the potential productivity of the crop (Anon, 2016). Many factors are responsible for low yield of potato such as seed quality, soil fertility, irrigation facilities, nutrient management, pest infestation, etc. (Iqbal et al., 2019). One of the majors constrains for potato cultivation is unavailability of quality and healthy seed tubers. Diseases and disorders are important for qualitative and quantitative tuber losses (Hossain et al., 2004). Among the diseases, tuber-borne diseases and disorders such as soft rot (Erwinia spp.), dry rot (Fusarium spp.), common scab (Streptomyces scabies) skin spot, black heart, heat injury, secondary growth, greening, etc., play important role in reduction of seed quality. Potato crops require a balanced fertilization for plant growth, and both yield and quality of tubers (Koch et al., 2020). One of the most important constrains of higher tuber yield is the lack of adequate balanced fertilizer application. Since 1980, farmers were using only NPK-fertilizers, but now they are applying $\mathrm{S}$ and $\mathrm{Zn}$ along with NPK. Many researchers are in opinion that application of minor nutrients such as $\mathrm{S}, \mathrm{Mg}, \mathrm{Zn}, \mathrm{B}$ in addition to essential major elements can play a good role in increasing the yield of potato (Sharma et al., 2011).

Plants are deficit to $\mathrm{Mg}$ in the soil having low $\mathrm{pH}$, sandy in nature and highly leached soil with low Cation Exchange Capacity. The most common symptom of $\mathrm{Mg}$ deficiency was observed in the potato field is plants showed interveinal chlorosis on the older leaves. Magnesium is an important constituent of chlorophyll molecule, therefore, essential for photosynthesis. Magnesium increase NPK uptake and thereby increase yield and promotes uptake and translocation of phosphorus (Guo et al., 2016). With NPK fertilizers supplemental $\mathrm{Mg}$ can increase yields and have tremendous effects on potato quality and net returns, even when soil test Mg levels seem adequate. Magnesium is also important in the activity of a large number of enzyme systems in plants, systems that are particularly important in the metabolism of carbohydrates. Magnesium plays a vital role in the adsorption of other nutrients especially phosphorous, potassium and calcium, acts as a catalyst, activators and co-factors in several enzymatic activities and participates in active protein and carbohydrate metabolism. Potatoes are highly sensitive to $\mathrm{Mg}$ nutrient deficiency than other crops. Mg deficiency is one of the most important factors for poor growth of potato in the peat and sandy soils. Mg deficiencies may be corrected through the use of magnesium sulfate (Epsom salts or Kieserite) in fertilizers.

Sharma et al. (2011) observed that sulfur application in potato showed significant influence on quality and yield. The highest tuber yield, large size and medium size tuber yield, dry matter content, specific gravity, sugar content and starch content were found with application of sulfur. Sulfur helps to minimize the 
diseases, for instance common and powdery scab. This effect may be due to a reduction in the soil $\mathrm{pH}$ where elemental sulfur is used. However, a programme of foliar S, can also reduce infection (Brierley et al., 2008). Sulfur can reduce common scab, late blight, stem canker of potato. In additionally, Sulfur can balance other nutrients and make the environment less favorable for the pathogen. Applications of elemental $\mathrm{S}$ to soil would control potato scab. It appears that the mechanism for control comes from the reduction in soil $\mathrm{pH}$. Elemental sulfur can aid in reducing the infection levels of common scab caused by the S. scabies. Best effects come from applying sulfur to the soil in a readily available form at planting. The application of sulfur significantly reduces the infection of Rhizoctonia solani and Streptomyces scabies and increase tuber yield. It may elucidate S-induced resistance mechanisms in plants (Hanna et al., 2006). Above discussion indicates that application of $\mathrm{Mg}$ and $\mathrm{S}$ may help in increasing production and quality of potato. Hence, to address these problems the study was undertaken with the major objective to investigate the effects of applying different levels of magnesium and sulfur on tuber yield and quality of seed potato.

\section{MATERIALS AND METHODS}

The experiment was conducted at Bangabandhu Sheikh Mujibur Rahman Agricultural University farm, Gazipur, Bangladesh (Map 1) during 2014-2016 to find out effect of Magnesium (Mg) and Sulfur (S) on plant growth, tuber yield and tuber health. $\mathrm{Mg}$ was applied at $0,10,15$ and $20 \mathrm{kgha}^{-1}$, which were designated as $\mathrm{Mg}_{0}, \mathrm{Mg}_{10}, \mathrm{Mg}_{15}$ and $\mathrm{Mg}_{20}$. Sulfur was applied at $0,10,20,30$ kgha $^{-1}$, which were designated as $S_{0}, S_{10}, S_{20}$ and $S_{30}$. In this experiment the treatment combinations were $\mathrm{Mg}_{0} \mathrm{~S}_{0}, \mathrm{Mg}_{0} \mathrm{~S}_{10}, \mathrm{Mg}_{0} \mathrm{~S}_{20}, \mathrm{Mg}_{0} \mathrm{~S}_{30}, \mathrm{Mg}_{10} \mathrm{~S}_{0}, \mathrm{Mg}_{10} \mathrm{~S}_{10}$, $\mathrm{Mg}_{10} \mathrm{~S}_{20}, \mathrm{Mg}_{10} \mathrm{~S}_{30}, \mathrm{Mg}_{15} \mathrm{~S}_{0}, \mathrm{Mg}_{15} \mathrm{~S}_{10}, \mathrm{Mg}_{15} \mathrm{~S}_{20}, \mathrm{Mg}_{15} \mathrm{~S}_{30}, \mathrm{Mg}_{20} \mathrm{~S}_{0}, \mathrm{Mg}_{20} \mathrm{~S}_{10}, \mathrm{Mg}_{20} \mathrm{~S}_{20}$ and $\mathrm{Mg}_{20} \mathrm{~S}_{30}$. Magnesium as magnesium chlorite $\left(\mathrm{MgCl}_{2} \cdot 6 \mathrm{H}_{2} \mathrm{O}\right)$ and Sulfur as gypsum $\left(\mathrm{CaSO}_{4} \cdot 2 \mathrm{H}_{2} \mathrm{O}\right)$ were used in the experiment.

Experimental site: The soil of the experimental field belongs to Salna series under the Agro Ecological Zone AEZ-28, Madhupur Tract $\left(24.05^{0} \mathrm{~N}\right.$ latitude and $90.16^{0} \mathrm{E}$ longitude) at an elevation of $8.4 \mathrm{~m}$ above the sea level. The texture of the soil was silty clay in surface layer and silty clay loam in subsurface layer. The results of soil test reveal that the soil contains $1.4 \%$ organic matter, magnesium $1.05 \mathrm{mE} / 100 \mathrm{~g}$ soil, sulfur $2.29 \mathrm{ppm}$ and $\mathrm{pH}$ 6.7-6.9. Land of the experimental plots was prepared in the month of November using a tractor driven harrow and disk plough followed by laddering to obtain a good tilth. Weeds and other debris were removed. Before ploughing cowdung based compost was applied at 10 tha $^{-1}$. A blank dosage of N, P, K, Zn and B was used at 140-35-1404-1.5 $\mathrm{kgha}^{-1}$ and applied as urea, TSP, MOP, zinc oxide and boric acid, respectively. One half dosage of NK and other nutrients were mixed with soil in furrows at the time of plantation of seed tuber. After final land preparation, experimental unit plots were prepared. The unit plot size was $2.25 \mathrm{~m} \times 2.40 \mathrm{~m}$. Plot to plot and block to block distance was $1 \mathrm{~m}$. The experiment was laid out in 
$4 \times 4$ factorial design in randomized complete block with three replications. The potato seed tubers of variety Diamant (basic class) were collected from Bangladesh Agricultural Development Corporation (BADC). Seed tubers were kept under defused light for sprouting. Sprouted tubers were planted in 5-7 cm deep furrows in $3^{\text {rd }}$ week of November. The planting spacing was $60 \mathrm{~cm}$ row to row and $15 \mathrm{~cm}$ tuber to tuber. Four lines were accommodated in each unit plot. Standard cultivation operations were followed to grow potato (Anon, 2008). First irrigation was applied one week after planting which was continued for several times as per requirement. After 20 days of planting weeding was done. To control the fungal diseases especially late blight, Dithane M-45 was applied at the rate of $2.5 \mathrm{kgha}^{-1}$ and to control aphids, Admire was applied at the rate of $1 \mathrm{Lha}^{-1}$. Both the pesticides were applied as foliar spray for six times at 10 days interval starting from 20 days of planting.

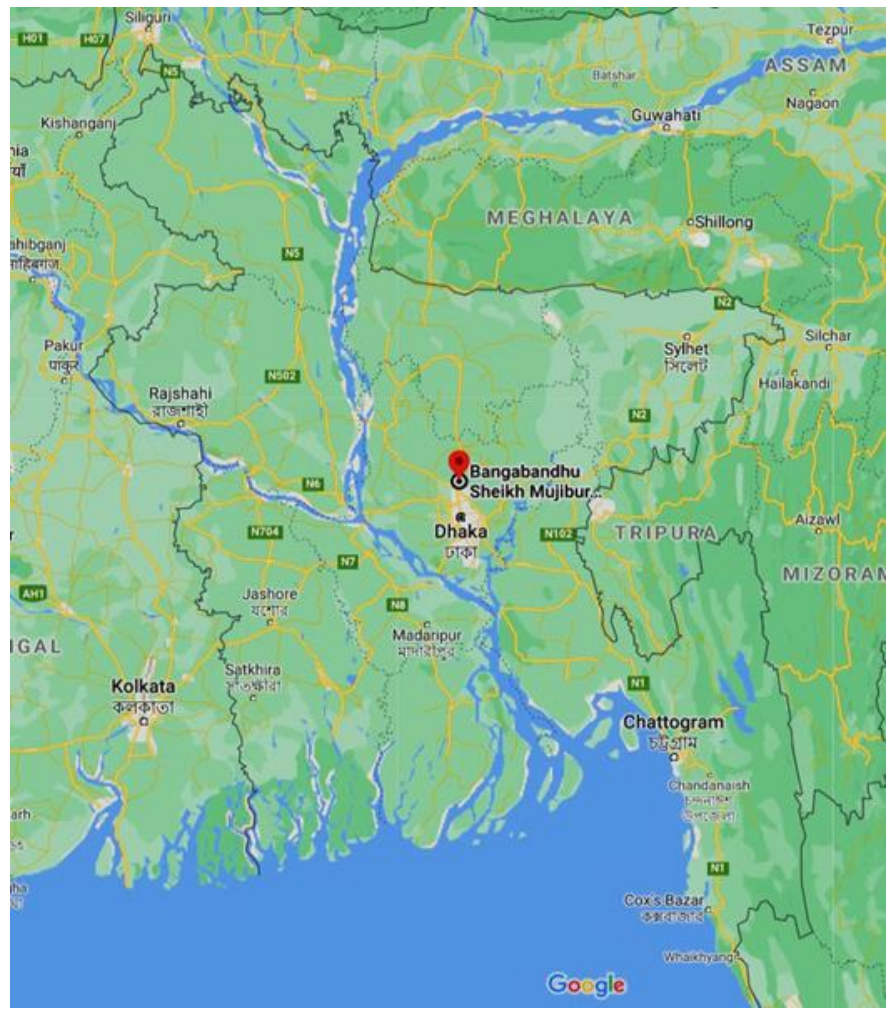

Map 1. Location of study area $\left(24^{\circ} 02^{\prime} 15.1^{\prime \prime} \mathrm{N}, 90^{\circ} 23^{\prime} 53.1^{\prime \prime} \mathrm{E}\right.$, https://goo.gl/maps/ivZHT7iRS4j23wUq7)

\section{Data recording}

Plant growth parameters: At 45 days after planting of seed tuber under different experiments, $15 \mathrm{~cm} \times 60 \mathrm{~cm}$ area was selected randomly and data on canopy coverage was recorded and expressed in percentage. At 60 days after 
planting 10 plants were selected randomly from each plot and data on plant growth attributes viz. number of stems per 10 hills and at 60 days after planting plant height was recorded. Stem killing was done on $80^{\text {th }}$ day of after planting to avoid spread of viruses and for hardening of tuber skin. After ten days of stem killing potato tubers were harvested manually and care was taken to avoid tuber injuries at harvest. Seven days after air drying healthy tubers were sorted out and graded into four grades on the basis of tuber size. Grading of tuber was done following a standard grading system based on size according to Bangladesh Agricultural Development Corporation (BADC) the only Government's seed producing agency in Bangladesh (Anon., 2008). The grades were undersize (20 $28 \mathrm{~mm})$, grade A $(28-41 \mathrm{~mm})$, grade B $(41-56 \mathrm{~mm})$ and oversize $(>56-60$ $\mathrm{mm})$. Data on plant growth and tuber yield attributes in terms of stem number per ten plants, plant height, canopy coverage, number of tubers per ten plants and tuber yield per unit plot were recorded.

Data on disease: Data on diseases and disorders were taken after 7 days of harvest and expressed percentage (w/w) based on per plot yield of potato. The disease was identified based on visible symptoms. Whenever necessary, the identification was confirmed by laboratory tests. The data on incidence (\%) of common scab, soft rot and dry rot were recorded. Data on different disease incidence were computed using a standard formula shown below:

\section{$\%$ incidence $=$ (Weight of infected tuber/Weight of total tuber $) \times 100$}

Statistical analysis: Data were analyzed statistically using Statistix 10 analytical software (https://www.statistix.com/) for proper interpretation of results. The data recorded on different parameters were subjected to analysis of variance (ANOVA) and the means were compared using least significant difference (LSD) test at 5\% level of significance. Graphs and figures were prepared as and when necessary for proper presentation of the data.

\section{Stem number per 10 hills}

\section{RESULTS AND DISCUSSION}

Main effect of Mg: The highest number of 53.3 stems per 10 hills was recorded at $10 \mathrm{~kg} \mathrm{Mg} \mathrm{ha}^{-1}\left(\mathrm{Mg}_{10}\right)$, which was statistically similar to $15 \mathrm{~kg}\left(\mathrm{Mg}_{15}\right)$ and $20 \mathrm{~kg} \mathrm{Mg} \mathrm{ha}{ }^{-1}\left(\mathrm{Mg}_{20}\right)$ but significantly higher compared to control. The lowest number of 47.5 stems per 10 hills was produced under control $\left(\mathrm{Mg}_{0}\right)$ (Fig. $1)$.

Main effect of sulfur: The highest number of 53.3 stems per hill was found at $S_{20}$, which was statistically similar to $S_{10}$ and $S_{0}$. The lowest stem number of 48.3 per 10 hills was observed in $S_{30}$, which was statistically similar to $\mathrm{S}_{0}$ and $\mathrm{S}_{10}$ (Fig. 2).

Interaction effect: The highest number of 56.7 stems per 10 hills was produced in treatment combination $\mathrm{Mg}_{10} \mathrm{~S}_{20}$, which was statistically similar to $\mathrm{Mg}_{20} \mathrm{~S}_{10}, \mathrm{Mg}_{10} \mathrm{~S}_{0}, \mathrm{Mg}_{10} \mathrm{~S}_{30}, \mathrm{Mg}_{15} \mathrm{~S}_{10}, \mathrm{Mg}_{15} \mathrm{~S}_{20}, \mathrm{Mg}_{20} \mathrm{~S}_{20}, \mathrm{Mg}_{0} \mathrm{~S}_{0}, \mathrm{Mg}_{0} \mathrm{~S}_{10}, \mathrm{Mg}_{0} \mathrm{~S}_{20}$, $\mathrm{Mg}_{10} \mathrm{~S}_{10}, \mathrm{Mg}_{15} \mathrm{~S}_{0}, \mathrm{Mg}_{15} \mathrm{~S}_{30}$ and $\mathrm{Mg}_{20} \mathrm{~S}_{30}$. The lowest stem number of 40.00 per 10 hills was recorded in $\mathrm{Mg}_{0} \mathrm{~S}_{30}$ which was statistically similar to $\mathrm{Mg}_{20} \mathrm{~S}_{0}$ (Table 1). 


\section{Plant height}

Main effect of magnesium: Significantly the highest plant height of $64.90 \mathrm{~cm}$ was recorded at $15 \mathrm{~kg} \mathrm{Mg} \mathrm{ha}^{-1}$, which was statistically different from its other doses. The lowest plant height of $57.40 \mathrm{~cm}$ was produced in control (Fig. $1)$.

Main effect of sulfur: The highest plant height of $63.40 \mathrm{~cm}$ was found at $20 \mathrm{~kg} \mathrm{~S}$ $\mathrm{ha}^{-1}$, which was statistically similar to $30 \mathrm{~kg} \mathrm{~S} \mathrm{ha}^{-1}$. The lowest plant height was observed in control $\left(\mathrm{S}_{0}\right)$ Application of caused significant increase in this parameter compared to control (Fig. 2).

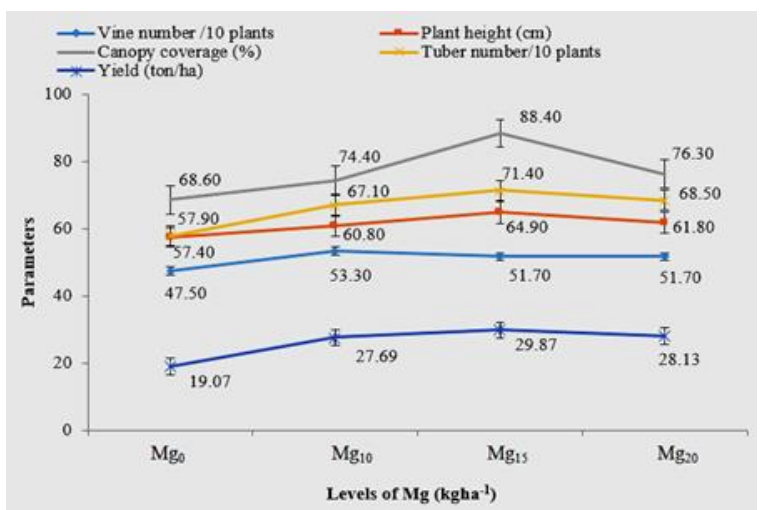

Fig 1. Effect of magnesium $(\mathrm{Mg})$ on growth and yield attributes of potato at different levels under a constant level of NPKBZn [ $\mathrm{Mg}_{0}=$ No magnesium, $\mathrm{Mg}_{10}$ $=10 \mathrm{~kg} \mathrm{Mg} \mathrm{ha}^{-1}, \mathrm{Mg}_{15}=35 \mathrm{~kg} \mathrm{Mg} \mathrm{ha}^{-1}, \mathrm{Mg}_{20}=20 \mathrm{~kg} \mathrm{Mg} \mathrm{ha}^{-1}$.]

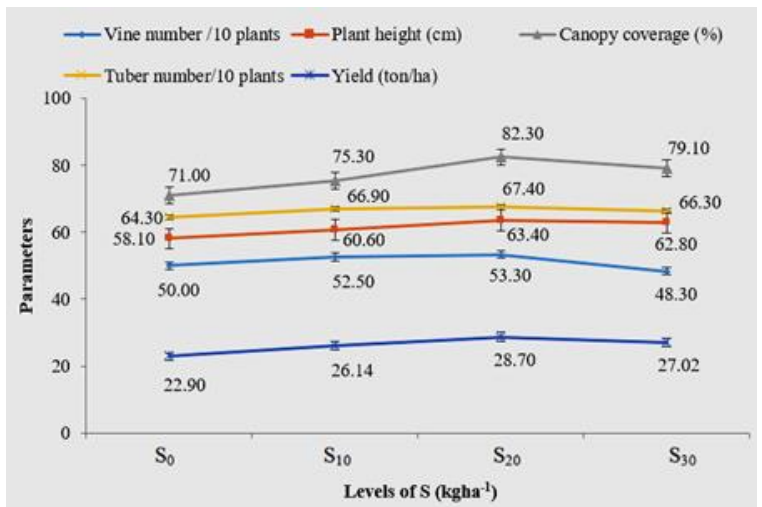

Fig 2. Effect of Sulfur (S) on growth and yield attributes of potato at different levels under a constant level of NPKBZn $\left[\mathrm{S}_{0}=\right.$ No sulfur, $\mathrm{S}_{10}=10 \mathrm{~kg} \mathrm{~S} \mathrm{ha}^{-1}, \mathrm{~S}_{20}=$ $20 \mathrm{~kg} \mathrm{~S} \mathrm{ha}^{-1}, \mathrm{~S}_{30}=30 \mathrm{~kg} \mathrm{Sha}^{-1}$.]

Interaction effect: Significantly the highest plant height of $69.0 \mathrm{~cm}$ was produced in $\mathrm{Mg}_{15} \mathrm{~S}_{20}$ which was different from other treatment combinations. The lowest plant height of $54.3 \mathrm{~cm}$ was recorded in control $\left(\mathrm{Mg}_{0} \mathrm{~S}_{0}\right)$ (Table 1). 
Table 1. Interaction effect of magnesium $(\mathrm{Mg})$ and sulfur $(\mathrm{S})$ on growth and yield attributes of potato at different levels under a constant level of NPKBZn

\begin{tabular}{|c|c|c|c|c|}
\hline $\begin{array}{l}\text { bevel of } \mathrm{Mg} \\
\text { Dose of } \mathrm{S}\end{array}$ & $\mathrm{Mg}_{0} *$ & $\mathrm{Mg}_{10}$ & $\mathrm{Mg}_{15}$ & $\mathrm{Mg}_{20}$ \\
\hline \multicolumn{5}{|c|}{ Stem number /10 plants } \\
\hline $\mathrm{S}_{0} *$ & $50.0 \mathrm{a}^{1}$ & $53.3 \mathrm{ab}$ & $50.0 \mathrm{ab}$ & $46.7 \mathrm{bc}$ \\
\hline$S_{10}$ & $50.0 \mathrm{ab}$ & $50.0 \mathrm{ab}$ & $53.3 \mathrm{ab}$ & $56.7 \mathrm{a}$ \\
\hline $\mathrm{S}_{20}$ & $50.0 \mathrm{ab}$ & $56.7 \mathrm{a}$ & $53.3 \mathrm{ab}$ & $53.3 \mathrm{ab}$ \\
\hline $\mathrm{S}_{30}$ & $40.0 \mathrm{c}$ & $53.3 \mathrm{ab}$ & $50.0 \mathrm{ab}$ & $50.0 \mathrm{ab}$ \\
\hline \multicolumn{5}{|c|}{ Plant height (cm) } \\
\hline $\mathrm{S}_{0}$ & $54.3 \mathrm{k}^{1}$ & $58.3 \mathrm{ij}$ & 61.0 efg & $58.7 \mathrm{hij}$ \\
\hline $\mathrm{S}_{10}$ & $57.3 \mathrm{j}$ & $60.0 \mathrm{ghi}$ & $63.7 \mathrm{~cd}$ & $61.3 \mathrm{efg}$ \\
\hline $\mathrm{S}_{20}$ & $57.3 \mathrm{j}$ & $63.0 \mathrm{cde}$ & $69.0 \mathrm{a}$ & $64.3 \mathrm{bc}$ \\
\hline $\mathrm{S}_{30}$ & $60.7 \mathrm{fgh}$ & $61.7 \mathrm{defg}$ & $66.0 \mathrm{~b}$ & $62.7 \mathrm{cdef}$ \\
\hline
\end{tabular}

Canopy coverage (\%)

\begin{tabular}{lllll}
\hline $\mathrm{S}_{0}$ & $65.0 \mathrm{j}^{1}$ & $67.0 \mathrm{i}$ & $82.0 \mathrm{de}$ & $70.0 \mathrm{~h}$ \\
$\mathrm{~S}_{10}$ & $66.7 \mathrm{ij}$ & $73.0 \mathrm{~g}$ & $87.0 \mathrm{c}$ & $74.7 \mathrm{~g}$ \\
$\mathrm{~S}_{20}$ & $69.7 \mathrm{~h}$ & $81.0 \mathrm{e}$ & $95.3 \mathrm{a}$ & $83.0 \mathrm{~d}$ \\
$\mathrm{~S}_{30}$ & $73.0 \mathrm{~g}$ & $76.7 \mathrm{f}$ & $89.3 \mathrm{~b}$ & $77.3 \mathrm{f}$ \\
\hline
\end{tabular}

Tuber number/10 plants

\begin{tabular}{lllll}
\hline $\mathrm{S}_{0}$ & $57.0 \mathrm{~g}^{1}$ & $63.8 \mathrm{f}$ & $68.4 \mathrm{cde}$ & $67.8 \mathrm{e}$ \\
$\mathrm{S}_{10}$ & $57.2 \mathrm{~g}$ & $67.1 \mathrm{e}$ & $72.7 \mathrm{ab}$ & $70.6 \mathrm{bc}$ \\
$\mathrm{S}_{20}$ & $58.4 \mathrm{~g}$ & $68.8 \mathrm{cde}$ & $74.4 \mathrm{a}$ & $68.2 \mathrm{de}$ \\
$\mathrm{S}_{30}$ & $58.9 \mathrm{~g}$ & $68.8 \mathrm{cde}$ & $70.2 \mathrm{~cd}$ & $67.2 \mathrm{e}$ \\
\hline
\end{tabular}

Seed Potato Tuber Yield (ton/ha)

\begin{tabular}{lllll}
\hline $\mathrm{S}_{0}$ & $16.41 \mathrm{j}^{1}$ & $22.94 \mathrm{~g}$ & $26.84 \mathrm{ef}$ & $25.39 \mathrm{f}$ \\
$\mathrm{S}_{10}$ & $18.30 \mathrm{i}$ & $28.26 \mathrm{de}$ & $29.83 \mathrm{bc}$ & $28.19 \mathrm{de}$ \\
$\mathrm{S}_{20}$ & $21.41 \mathrm{~h}$ & $30.64 \mathrm{~b}$ & $32.86 \mathrm{a}$ & $29.90 \mathrm{bc}$ \\
$\mathrm{S}_{30}$ & $20.15 \mathrm{~h}$ & $28.93 \mathrm{~cd}$ & $29.96 \mathrm{bc}$ & $29.04 \mathrm{~cd}$
\end{tabular}

* $\mathrm{Mg}_{0}=$ No magnesium, $\mathrm{Mg}_{10}=10 \mathrm{~kg} \mathrm{Mg} \mathrm{ha}{ }^{-1}, \mathrm{Mg}_{15}=15 \mathrm{~kg} \mathrm{Mg} \mathrm{ha}^{-1}, \mathrm{Mg}_{20}=20$ $\mathrm{kg} \mathrm{Mg} \mathrm{ha}{ }^{-1} .{ }^{*} S_{0}=$ No sulfur, $S_{10}=10 \mathrm{~kg} \mathrm{~S} \mathrm{ha}^{-1}, S_{20}=20 \mathrm{~kg} \mathrm{~S} \mathrm{ha}^{-1}, S_{30}=30 \mathrm{~kg} \mathrm{~S}$ $\mathrm{ha}^{-1}$. ${ }^{1}$ Figures under the same parameter within row and column are averages of three replications and having a common letter(s) do not differ significantly ( $P=$ $0.05)$ by LSD test.

\section{Canopy coverage}

Main effect of magnesium: The maximum of $88.4 \%$ canopy coverage was recorded at $15 \mathrm{Kg} \mathrm{Mg} \mathrm{ha}{ }^{-1}\left(\mathrm{Mg}_{15}\right)$, which was statistically different from other treatments. The minimum canopy coverage of $68.6 \%$ in control was also statistically different from other treatments (Fig. 1).

Main effect of sulfur: The maximum canopy coverage of $82.3 \%$ was recorded at $20 \mathrm{Kg} \mathrm{S} \mathrm{ha}^{-1}\left(\mathrm{~S}_{20}\right)$ and the minimum canopy coverage of $71.0 \%$ were found in control, which was statistically different from other treatments (Fig. 2). 
Interaction effect: The canopy coverage under different treatment combination of $\mathrm{Mg}$ and $\mathrm{S}$ ranged from $95.3 \%$ to $65.0 \%$. The highest canopy coverage of $95.3 \%$ was found at $\mathrm{Mg}_{15} \mathrm{~S}_{20}$, which was not significantly different from other treatment combinations. The lowest canopy coverage of $65.0 \%$ was found under control, which was statistically similar to $\mathrm{Mg}_{0} \mathrm{~S}_{10}(66.7 \%)$ (Table 1).

\section{Tuber per ten plants}

Main effect of magnesium: The minimum tuber number of 57.9 per 10 plants was recorded from control, which was significantly increased due to application of $\mathrm{Mg}$ at different levels. The maximum average number of 71.4 tubers per 10 plants was found at $\mathrm{Mg}_{15}$ (Fig. 1).

Main effect of sulfur: The maximum average number of 67.4 tubers 10 per plants was observed at $S_{20}$, which was statistically similar to $S_{10}$. The minimum tuber number of $64.3 \%$ per 10 plants was recorded under control (Fig. 2).

Interaction effect of $\mathbf{M g}$ and $\mathbf{S}$ : The maximum average number of 74.4 tubers per 10 plants was obtained from $\mathrm{Mg}_{15} \mathrm{~S}_{20}$, which was similar to $\mathrm{Mg}_{15} \mathrm{~S}_{10}$. The minimum number of 57.0 tubers per 10 plants was found under control, which was statistically similar to $\mathrm{Mg}_{0} \mathrm{~S}_{10}, \mathrm{Mg}_{0} \mathrm{~S}_{20}$ and $\mathrm{Mg}_{0} \mathrm{~S}_{30}$ (Table 1).

Seed Potato Tuber Yield (tha ${ }^{-1}$ )

Main effect of magnesium: The lowest tuber yield of 19.07 tha $^{-1}$ was produced in control plot, which was increased to 29.87 tha $^{-1}$. The highest yield per plot of 29.87 tha $^{-1}$ was produced at $\mathrm{Mg}_{15}$ (Fig.1).

Main effect of sulfur: The significantly highest yield was obtained with served 28.70 tha $^{-1}$ at $20 \mathrm{~kg} \mathrm{~S} \mathrm{ha}^{-1}\left(\mathrm{~S}_{20}\right)$ and the lowest yield per plot was found 22.90 tha $^{-1}$ under control, which was significantly different from other treatments (Fig. 2).

Interaction effect of $\mathbf{M g}$ and $\mathbf{S}$ : The average highest yield of 32.86 tha $^{-1}$ was found at $\mathrm{Mg}_{15} \mathrm{~S}_{20}$, which was different from other treatment combinations and the lowest yield per plant was 16.41 tha $^{-1}$ under control, which was statistically similar to $\mathrm{Mg}_{0} \mathrm{~S}_{10}$ and $\mathrm{Mg}_{0} \mathrm{~S}_{30}$ (Table 1).

Grading of healthy tubers: Healthy tubers were graded into four grades based on their size. These were Grade-A (diameter 28-41 mm), grade-B (diameter 41-55 mm), undersize (diameter 20-28 mm) and oversize (diameter 55-60 mm). Occurrence of tuber under each grade was expressed as percentage of total healthy tubers. Occurrence of grade-B tubers was maximal followed by grade-A, undersize and oversize tuber (Fig. 3).

\section{Grade A (diameter 28-41 mm)}

Main effect of magnesium: The highest grade-A seed tuber of $27.48 \%$ was recorded at $20 \mathrm{kgha}^{-1}$, which was statistically similar to $10 \mathrm{kgha}^{-1}$. The lowest Grade-A seed was produced at control ( $\left.\mathrm{Mg}_{0}\right)$ (Fig. 3).

Main effect of sulfur: The highest occurrence of grade A seed tuber of $27.41 \%$ was found at $30 \mathrm{~kg} \mathrm{Sha}^{-1}$ which was statistically similar to $20 \mathrm{~kg} \mathrm{~S}^{-1}$. The lowest occurrence Grade A seed was observed in control $\left(\mathrm{S}_{0}\right)$ which was statistically similar with $10 \mathrm{~kg} \mathrm{~S} \mathrm{ha}^{-1}$ 


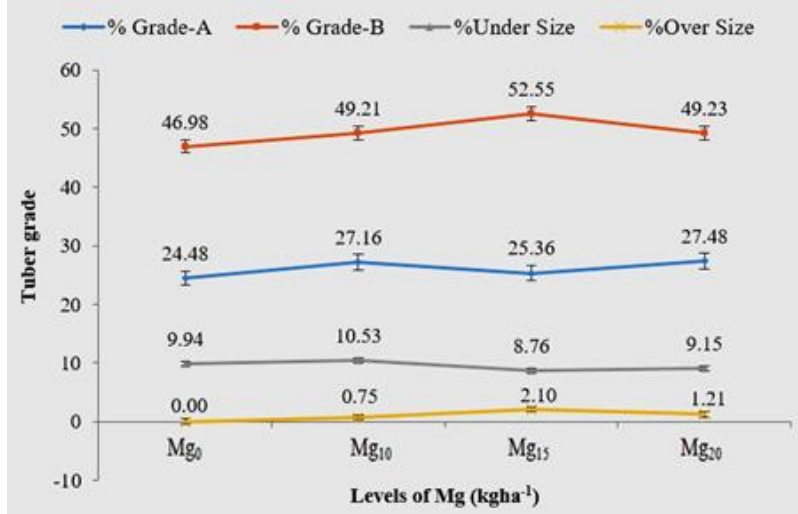

Fig 3. Main effect of $\mathrm{Mg}$ on occurrence of different grades of tubers under a constant level of NPKBZn $\left[\mathrm{Mg}_{0}=\right.$ No magnesium, $\mathrm{Mg}_{10}=10 \mathrm{~kg} \mathrm{Mg} \mathrm{ha}{ }^{-1}, \mathrm{Mg}_{15}=$ $\left.15 \mathrm{~kg} \mathrm{Mg} \mathrm{ha}{ }^{-1}, \operatorname{Mg}_{20}=20 \mathrm{~kg} \mathrm{Mg} \mathrm{ha}^{-1}\right]$

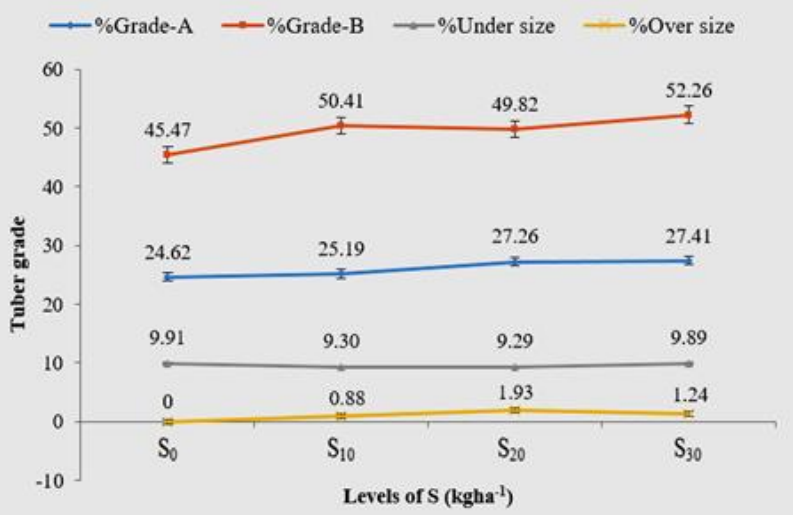

Fig 4. Main effect of $S$ on occurrence of different grades of tubers under a constant level of NPKBZn $\left[S_{0}=\right.$ No sulfur, $S_{10}=10 \mathrm{~kg} \mathrm{~S} \mathrm{ha}^{-1}, \mathrm{~S}_{20}=20 \mathrm{~kg} \mathrm{~S}^{-1}$, $\left.\mathrm{S}_{30}=30 \mathrm{~kg} \mathrm{~S} \mathrm{ha}^{-1}\right]$

Interaction effect of $\mathbf{M g}$ and $\mathbf{S}$ : The highest-Grade A seed tuber (29.41\%) was produced in $\mathrm{Mg}_{10} \mathrm{~S}_{20}$ which was statistically similar with $\mathrm{Mg}_{10} \mathrm{~S}_{30}$, $\mathrm{Mg}_{0} \mathrm{~S}_{30}, \mathrm{Mg}_{20} \mathrm{~S}_{10}, \mathrm{Mg}_{20} \mathrm{~S}_{0}, \mathrm{Mg}_{20} \mathrm{~S}_{30}$ and $\mathrm{Mg}_{20} \mathrm{~S}_{20}$. The lowest Grade A seed tuber $(20.18 \%)$ was recorded in control $\left(\mathrm{Mg}_{0} \mathrm{~S}_{0}\right)$ which was statistically similar with $\mathrm{Mg}_{0} \mathrm{~S}_{10}$ (Table 2).

\section{Grade B (diameter 41-55 mm)}

Main effect of magnesium: The highest grade-B seed was found $52.55 \%$ at $15 \mathrm{~kg} \mathrm{Mg} \mathrm{ha}{ }^{-1}\left(\mathrm{Mg}_{15}\right)$, which was significantly different from other treatments. The lowest grade-B of $46.98 \%$ was recorded from control significantly higher compared to other treatments (Fig. 3)

Main effect of sulfur: The main effect was significant. The highest occurrence of $52.26 \%$ grade-B tubers was recorded at $30 \mathrm{~kg} \mathrm{ha}^{-1}\left(\mathrm{~S}_{30}\right)$ and the lowest occurrence of $45.47 \%$ grade-B tubers was observed under control, which was significantly higher from other treatment combinations 
Table 2. Interaction effect of magnesium $(\mathrm{Mg})$ and sulfur $(\mathrm{S})$ on tuber grade size at different levels under a constant level of NPKBZn

\begin{tabular}{|c|c|c|c|c|}
\hline $\begin{array}{l}\text { Lekel of } \mathrm{Mg} \\
\text { Dose of } \mathrm{S}\end{array}$ & $\mathrm{Mg}_{0} *$ & $\mathrm{Mg}_{10}$ & $\mathrm{Mg}_{15}$ & $\mathrm{Mg}_{20}$ \\
\hline \multicolumn{5}{|c|}{ \% Grade-A (28-41mm) } \\
\hline $\mathrm{S}_{0} *$ & $20.18 \mathrm{~g}^{1}$ & $25.70 \mathrm{cde}$ & $25.04 \mathrm{de}$ & $27.55 \mathrm{abc}$ \\
\hline $\mathrm{S}_{10}$ & $22.44 \mathrm{fg}$ & 24.46 ef & 26.17 cde & $27.7 \mathrm{abc}$ \\
\hline $\mathrm{S}_{20}$ & 26.77 bcde & $29.41 \mathrm{a}$ & 25.72 cde & $27.13 \mathrm{abcd}$ \\
\hline $\mathrm{S}_{30}$ & $28.55 \mathrm{ab}$ & $29.07 \mathrm{ab}$ & $24.5 \mathrm{ef}$ & $27.52 \mathrm{abc}$ \\
\hline \multicolumn{5}{|c|}{ \% Grade-B (41-55 mm) } \\
\hline $\mathrm{S}_{0}$ & $45.42 \mathrm{fg}^{1}$ & $43.14 \mathrm{~g}$ & 49.12 cde & $44.2 \mathrm{~g}$ \\
\hline$S_{10}$ & $48.03 \mathrm{ef}$ & $51.3 \mathrm{bcd}$ & $52.07 \mathrm{bc}$ & $50.26 \mathrm{cde}$ \\
\hline $\mathrm{S}_{20}$ & $45.44 \mathrm{fg}$ & $48.62 \mathrm{de}$ & $53.82 \mathrm{ab}$ & $51.4 \mathrm{bcd}$ \\
\hline $\mathrm{S}_{30}$ & 49.02 cde & $53.77 \mathrm{ab}$ & $55.19 \mathrm{a}$ & 51.07 bcde \\
\hline \multicolumn{5}{|c|}{$\%$ Under size (20-28mm) } \\
\hline $\mathrm{S}_{0}$ & $7.93 \mathrm{e}^{1}$ & $13.36 \mathrm{a}$ & 9.13 cde & 9.2 cde \\
\hline$S_{10}$ & $8.67 \mathrm{de}$ & $11.01 \mathrm{~b}$ & $8.88 \mathrm{de}$ & $8.64 \mathrm{de}$ \\
\hline $\mathrm{S}_{20}$ & $10.57 \mathrm{bc}$ & $8.87 \mathrm{de}$ & $8.57 \mathrm{de}$ & 9.14 cde \\
\hline $\mathrm{S}_{30}$ & $12.59 \mathrm{a}$ & $8.89 \mathrm{de}$ & $8.44 \mathrm{de}$ & $9.62 \mathrm{bcd}$ \\
\hline \multicolumn{5}{|c|}{$\%$ Over size (>55-60mm) } \\
\hline $\mathrm{S}_{0}$ & $0 \mathrm{c}^{1}$ & $0 \mathrm{c}$ & $0 \mathrm{c}$ & $0 \mathrm{c}$ \\
\hline$S_{10}$ & $0 \mathrm{c}$ & $0 \mathrm{c}$ & $2.74 \mathrm{~b}$ & $0.80 \mathrm{c}$ \\
\hline $\mathrm{S}_{20}$ & $0 \mathrm{c}$ & $0 \mathrm{c}$ & $4.51 \mathrm{a}$ & $3.19 \mathrm{ab}$ \\
\hline $\mathrm{S}_{30}$ & $0 \mathrm{c}$ & $3.00 \mathrm{~b}$ & $1.13 \mathrm{c}$ & $0.83 \mathrm{c}$ \\
\hline
\end{tabular}

* $\mathrm{Mg}_{0}=$ No magnesium, $\mathrm{Mg}_{10}=10 \mathrm{~kg} \mathrm{Mg} \mathrm{ha}{ }^{-1}, \mathrm{Mg}_{15}=15 \mathrm{~kg} \mathrm{Mg} \mathrm{ha}^{-1}, \mathrm{Mg}_{20}=20$ $\mathrm{kg} \mathrm{Mg} \mathrm{ha}{ }^{-1},{ }^{*} \mathrm{~S}_{0}=$ No sulfur, $\mathrm{S}_{10}=10 \mathrm{~kg} \mathrm{~S} \mathrm{ha}^{-1}, \mathrm{~S}_{20}=20 \mathrm{~kg} \mathrm{~S} \mathrm{ha}^{-1}, \mathrm{~S}_{30}=30 \mathrm{~kg} \mathrm{~S}$ $\mathrm{ha}^{-1}$. ${ }^{1}$ Figures under the same parameter within row and column are averages of three replications and having a common letter(s) do not differ significantly $(P=$ 0.05 ) by LSD test.

Interaction effect: Interaction effect of $\mathrm{Mg}$ and $\mathrm{S}$ on grade-B tubers was significant. The highest grade-B 55.19\% seed tubers were found at $\mathrm{Mg}_{15} \mathrm{~S}_{30}$, which was statistically similar to $\mathrm{Mg}_{15} \mathrm{~S}_{20}$ and $\mathrm{Mg}_{10} \mathrm{~S}_{30}$. The lowest occurrence of $43.14 \%$ grade-B seed tuber was found at $\mathrm{Mg}_{10} \mathrm{~S}_{0}$, which was statistically similar to $\mathrm{Mg}_{20} \mathrm{~S}_{0}, \mathrm{Mg}_{0} \mathrm{~S}_{0}$ and $\mathrm{Mg}_{0} \mathrm{~S}_{20}$ (Table 2).

\section{Undersize (diameter 20-28 mm)}

Main effect of magnesium: The highest occurrence of only $10.53 \%$ undersize seed tuber was produced due to application of $\mathrm{Mg}$ at $10 \mathrm{~kg} \mathrm{ha}^{-1}$, which was statistically similar to control $\left(\mathrm{gha}^{-1}\right)$. The lowest occurrence of $8.76 \%$ undersize seed tuber was recorded in $15 \mathrm{~kg} \mathrm{Mg} \mathrm{ha}{ }^{-1}$ which was statistically similar to $20 \mathrm{~kg} \mathrm{Mg} \mathrm{ha}^{-1}$ (Fig. 3).

Main effect of sulfur: No significant different was observed in under size tuber due to sulfur. The highest under size seed tuber $(9.91 \%)$ was observed 
in control $\left(\mathrm{S}_{0}\right)$ and the lowest under size seed tuber (9.29\%) was in $20 \mathrm{~kg} \mathrm{~S} \mathrm{ha}^{-1}$ (Fig. 4).

Interaction effect: The highest under size seed was found in $\mathrm{Mg}_{10} \mathrm{~S}_{0}$ $(13.36 \%)$ which was statistically similar with $\mathrm{Mg}_{0} \mathrm{~S}_{30}$. On the other hand, the lowest healthy under size seed was recorded in control $\mathrm{Mg}_{0} \mathrm{~S}_{0}(7.93 \%)$ which was statistically similar with $\mathrm{Mg}_{15} \mathrm{~S}_{30}, \mathrm{Mg}_{15} \mathrm{~S}_{20}, \mathrm{Mg}_{20} \mathrm{~S}_{10}, \mathrm{Mg}_{0} \mathrm{~S}_{10}, \mathrm{Mg}_{10} \mathrm{~S}_{20}, \mathrm{Mg}_{15} \mathrm{~S}_{10}$, $\mathrm{Mg}_{10} \mathrm{~S}_{30}, \mathrm{Mg}_{15} \mathrm{~S}_{0}, \mathrm{Mg}_{20} \mathrm{~S}_{20}$ and $\mathrm{Mg}_{20} \mathrm{~S}_{0}$ (Table 2).

\section{Oversize (diameter $>55-60 \mathrm{~mm}$ )}

Main effect of magnesium: Oversize tubers were not produced in absence of $\mathrm{Mg}$ (control) and lowest level of the element. The maximum occurrence of $2.10 \%$ tubers was recorded at $15 \mathrm{~kg} \mathrm{Mg} \mathrm{ha}^{-1}$ of the element (Fig. 3).

Main effect of sulfur: The highest occurrence of only $1.93 \%$ oversize seed tuber was recorded at $20 \mathrm{~kg} \mathrm{ha}^{-1}\left(\mathrm{~S}_{20}\right)$ and there was no oversize seed tuber was observed under control (Fig. 4).

Interaction effect: The highest occurrence of only $4.51 \%$ oversize seed tuber was found at $\mathrm{Mg}_{15} \mathrm{~S}_{20}$, which was statistically similar to $\mathrm{Mg}_{20} \mathrm{~S}_{20}$. Oversize seed tuber was not formed at the treatment combinations $\mathrm{Mg}_{20} \mathrm{~S}_{0}, \mathrm{Mg}_{15} \mathrm{~S}_{0}$, $\mathrm{Mg}_{10} \mathrm{~S}_{20}, \mathrm{Mg}_{10} \mathrm{~S}_{10}, \mathrm{Mg}_{10} \mathrm{~S}_{0}, \mathrm{Mg}_{0} \mathrm{~S}_{30}, \mathrm{Mg}_{0} \mathrm{~S}_{20}, \mathrm{Mg}_{0} \mathrm{~S}_{10}$ and $\mathrm{Mg}_{0} \mathrm{~S}_{0}$ which were statistically similar with $\mathrm{Mg}_{20} \mathrm{~S}_{10}, \mathrm{Mg}_{20} \mathrm{~S}_{30}, \mathrm{Mg}_{15} \mathrm{~S}_{30}$ (Table 2).

Incidence of diseases: Like experiment 1 , three important potato diseases were recorded from harvested tubers. The diseases were common scab, soft rot and dry rot.

\section{Incidence of common scab}

Main effect of Mg: Main effect of Mg on common scab was significant. The highest common scab incidence was $7.01 \%(\mathrm{w} / \mathrm{w})$ was under control $\left(\mathrm{Mg}_{0}\right)$. Application of $\mathrm{Mg}$ caused significant decrease in disease incidence showing the lowest common scab incidence of 5.10\% at $\mathrm{Mg}_{10}$ (Fig. 5).

Main effect of sulfur: The main effect of $\mathrm{S}$ on common scab was also significant. The highest incidence of $9.66 \%(\mathrm{w} / \mathrm{w})$ of common scab was found under control $\left(\mathrm{S}_{0}\right)$. Application of $\mathrm{S}$ reduced the disease incidence significantly over control $\left(\mathrm{S}_{0}\right)$. The lowest incidence of $3.33 \%$ common scab disease was recorded under $S_{30}$, which was statistically similar to $S_{20}$ (Fig. 6).

Incidence of soft rot and dry rot: The main effect of $\mathrm{Mg}$ and $\mathrm{S}$ on incidence of soft rot and dry rot was very low. The incidence soft rot and dry rot under $\mathrm{Mg}$ ranged $0.87-2.76 \%$ and $0.25-0.82 \%$, respectively. Their incidence under $\mathrm{S}$ ranged $1.17-2.34 \%$ and $0.37-0.73 \%$, respectively (Fig. 5 and 6).

Interaction effect of $\mathbf{M g}$ and $\mathbf{S}$ on total disease incidence: The maximum total disease incidence was recorded under control $\left(\mathrm{Mg}_{0} \mathrm{~S}_{0}\right)$. Combined application of $\mathrm{Mg}$ and $\mathrm{S}$ caused significant decrease in disease incidence over control. The decreasing tendency incidence continued up to $\mathrm{Mg}_{15} \mathrm{~S}_{20}$ (Fig. 7).

Incidence of disorders: Different disorders such as secondary growth and greening were found in harvested potato tubers, but their incidence was negligible (Fig. 8). So the details are not given. 


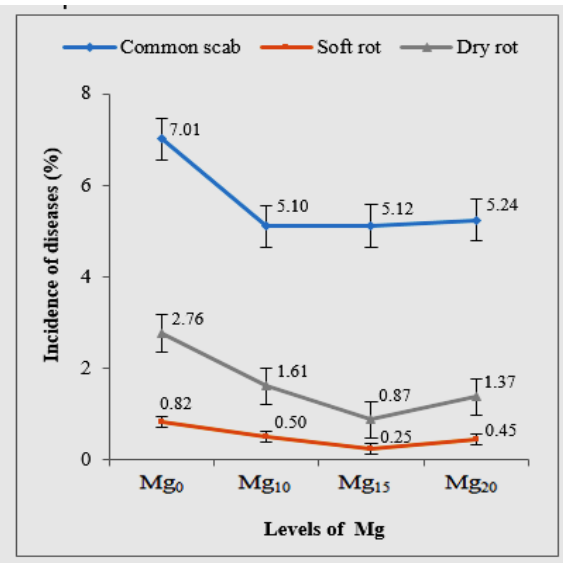

Figure 5. Incidence of common scab, soft rot and dry rot diseases at different levels of magnesium

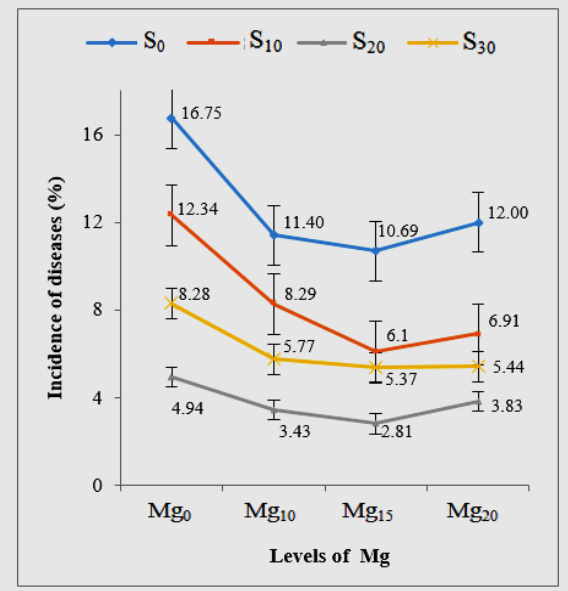

Figure 7. Interaction effect of $\mathrm{Mg}$ and $\mathrm{S}$ on incidence of total diseases

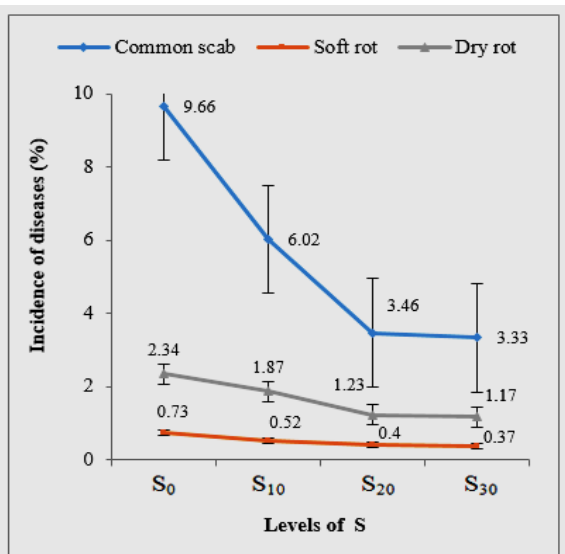

Figure 6. Incidence of common scab, soft rot and dry rot diseases at different levels of sulfur

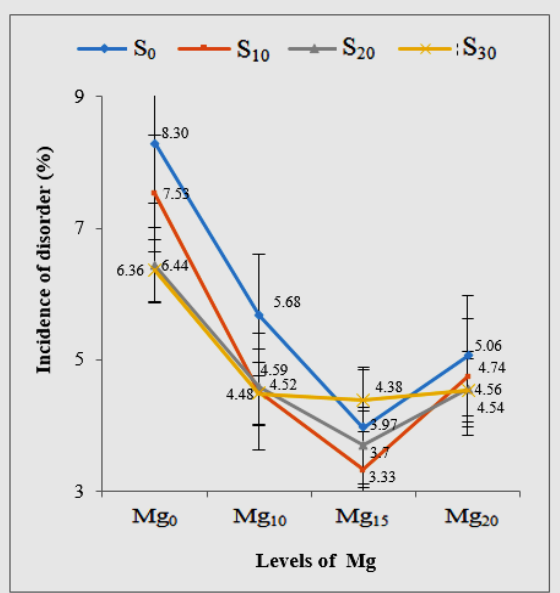

Figure 8. Interaction effect of $\mathrm{Mg}$ and $\mathrm{S}$ on incidence of total disorders

\section{Estimation of optimum level of magnesium and sulfur}

Regression analysis was done and optimum and economic dose of fertilizer were calculated using the formula $\mathrm{Y}=-\mathrm{b} / 2 \mathrm{c}$ from the response curve (Gomez and Gomez, 1984). Dobermann et al. (2000) stated that the optimal rate of fertilizer application to a crop is that rate which produces the maximum economic returns at the minimum cost, and this can be derived from a nutrient response curve. The large and significant $\mathrm{R}^{2}$ value in case of $\mathrm{Mg}$ and $\mathrm{S}$ of regression indicates that the quadratic response fitted the data. Response curve shows that yield increased with the increasing of nutrients at certain level and thereafter yield was decreased. Results presented in Fig 9 shows that potato tuber yield increased with increasing level of Magnesium to a certain limit and then decreased with further increase of nutrients level. But the increment of yield was 
prominent in case of $\mathrm{Mg}$ and the highest yield (29.87 tha $\left.\mathrm{a}^{-1}\right)$ was obtained from 15 $\mathrm{kg} \mathrm{Mg} \mathrm{ha}{ }^{-1}$. Magnesium has distinct effect on the yield. But further application of $\mathrm{Mg}$ yield began to decrease. It was indicating the detrimental effect of over fertilization. The reason might be medium $\mathrm{Mg}$ status in soil. From the regression equations optimum dose of Magnesium fertilizer is $15.28 \mathrm{~kg} \mathrm{ha}^{-1}$ for better yield. In case of sulfur, potato tuber yield was also increased with increasing level of sulfur fertilizer to a certain limit and then decreased with further increase of nutrients level (Fig. 20). The highest yield $\left(28.70\right.$ tha $\left.^{-1}\right)$ was obtained from $20 \mathrm{~kg}$ $\mathrm{S} \mathrm{ha}{ }^{-1}$. But further application of $\mathrm{S}$ yield began to decrease. The reason might be medium $S$ status in soil. The regression equations suggested that optimum dose of sulfur fertilizer is $21.11 \mathrm{~kg} \mathrm{ha}^{-1}$ for better seed tuber yield (Table 3).

The results of present experiment suggest that growth parameters, yield and yield components of potato are responded positively to $\mathrm{Mg}$ and S fertilizers either applied as sole or in combination. The average tuber weight, healthy seed tuber and total tuber yield was positively and significantly influenced by different levels of $\mathrm{Mg}$ and $\mathrm{S}$ fertilizer and their interaction. The highest tuber yield, average tuber weight, number of tubers per plant and number of stem per hill were obtained from application of $\mathrm{Mg}$ and $\mathrm{S}$ fertilizer in combination at the rate of $15 \mathrm{Kg} \mathrm{Mg} \mathrm{ha}^{-1}$ and $20 \mathrm{Kg} \mathrm{S}^{-1}$. Other researchers also found positive effect of $\mathrm{Mg}$ and S fertilizer on growth and yield. Talukder et al. (2009) tested 5 levels of magnesium viz., $0,5,10,15$, and $20 \mathrm{~kg} \mathrm{ha}^{-1}$ to observe its effects on potato and to find out the optimum and economic dose of $\mathrm{Mg}$ for potato.

Table 3. Regression equation and Optimum dose of Magnesium and Sulfur fertilizer

\begin{tabular}{|c|c|c|c|c|}
\hline $\begin{array}{l}\text { Nutrients } \\
\text { levels } \\
\left(\mathrm{kgha}^{-1}\right)\end{array}$ & $\begin{array}{l}\text { Seed } \\
\text { potato } \\
\text { tuber } \\
\text { yield } \\
\left(\text { tha }^{-1}\right)\end{array}$ & $\begin{array}{l}\text { Yield } \\
\text { increased } \\
\text { over } \\
\text { control } \\
(\%)\end{array}$ & $\begin{array}{l}\text { Regression equation and } \\
\mathrm{R}^{2} \text { value }\end{array}$ & $\begin{array}{l}\text { Optimum dose } \\
\text { of fertilizer } \\
\left(\mathrm{kg} \mathrm{ha}^{-1}\right)\end{array}$ \\
\hline \multicolumn{5}{|c|}{ Magnesium Levels } \\
\hline $\begin{array}{l}\mathrm{Mg}_{0} \\
\mathrm{Mg}_{10} \\
\mathrm{Mg}_{15} \\
\mathrm{Mg}_{20} \\
\end{array}$ & $\begin{array}{l}19.07 \\
27.69 \\
29.87 \\
28.13 \\
\end{array}$ & $\begin{array}{l}- \\
45.24 \\
56.67 \\
47.53 \\
\end{array}$ & $\begin{array}{l}\mathrm{y}=-0.0443 \mathrm{x}^{2}+1.3538 \mathrm{x} \\
+ \\
\mathrm{R}^{2}=0.9927\end{array}$ & 15.28 \\
\hline \multicolumn{5}{|c|}{ Sulfur Levels } \\
\hline $\begin{array}{l}S_{0} \\
S_{10} \\
S_{20} \\
S_{30} \\
\end{array}$ & $\begin{array}{l}22.90 \\
26.14 \\
28.70 \\
27.02 \\
\end{array}$ & $\begin{array}{l}- \\
14.19 \\
25.37 \\
18.01\end{array}$ & $\begin{array}{l}\mathrm{y}=-0.0123 \mathrm{x}^{2}+0.5193 \mathrm{x} \\
+ \\
+ \\
\mathrm{R}^{2}=0.9646\end{array}$ & 21.11 \\
\hline
\end{tabular}

$\mathrm{Mg}_{0}=0 \mathrm{~kg} \mathrm{Mg} \mathrm{ha}{ }^{-1}, \mathrm{Mg}_{10}=10 \mathrm{~kg} \mathrm{Mg} \mathrm{ha}{ }^{-1}, \mathrm{Mg}_{15}=15 \mathrm{~kg} \mathrm{Mg} \mathrm{ha}^{-1}, \mathrm{Mg}_{20}=20 \mathrm{~kg}$ $\mathrm{Mg} \mathrm{ha}^{-1} . \mathrm{S}_{0}=0 \mathrm{~kg} \mathrm{~S} \mathrm{ha}^{-1}, \mathrm{~S}_{10}=10 \mathrm{~kg} \mathrm{~S} \mathrm{ha}^{-1}, \mathrm{~S}_{20}=20 \mathrm{~kg} \mathrm{~S} \mathrm{ha}^{-1}, \mathrm{~S}_{30}=30 \mathrm{~kg} \mathrm{~S} \mathrm{ha}^{-1}$. 


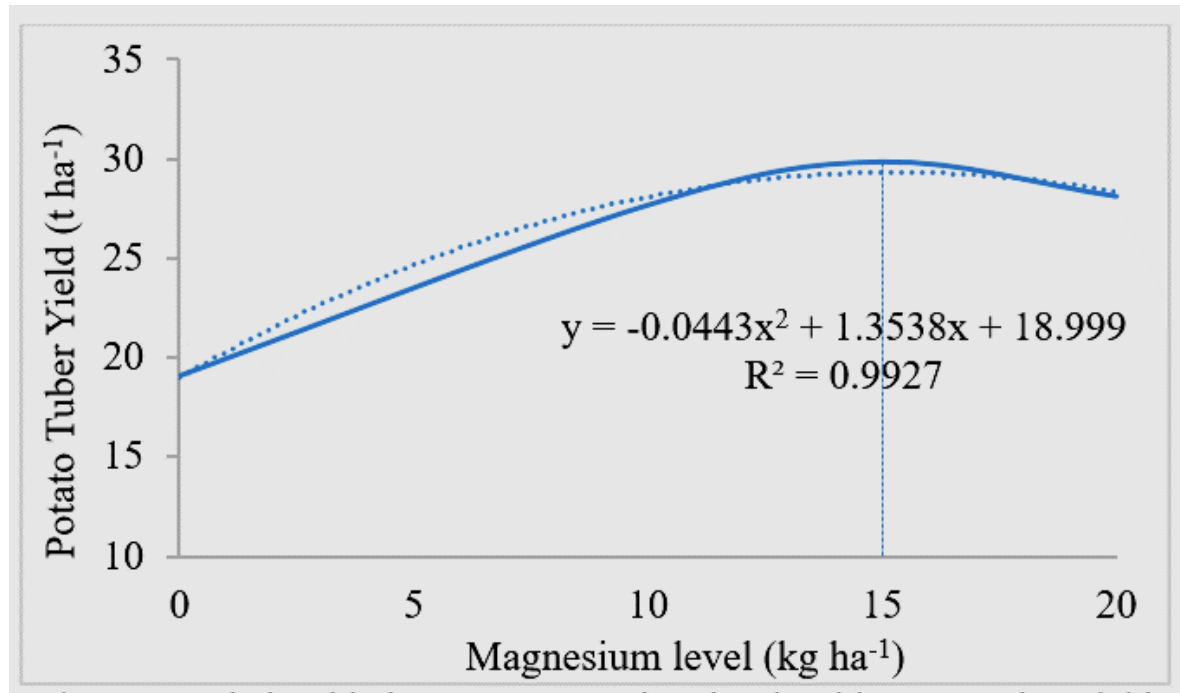

Figure 9. Relationship between magnesium levels with potato tuber yield

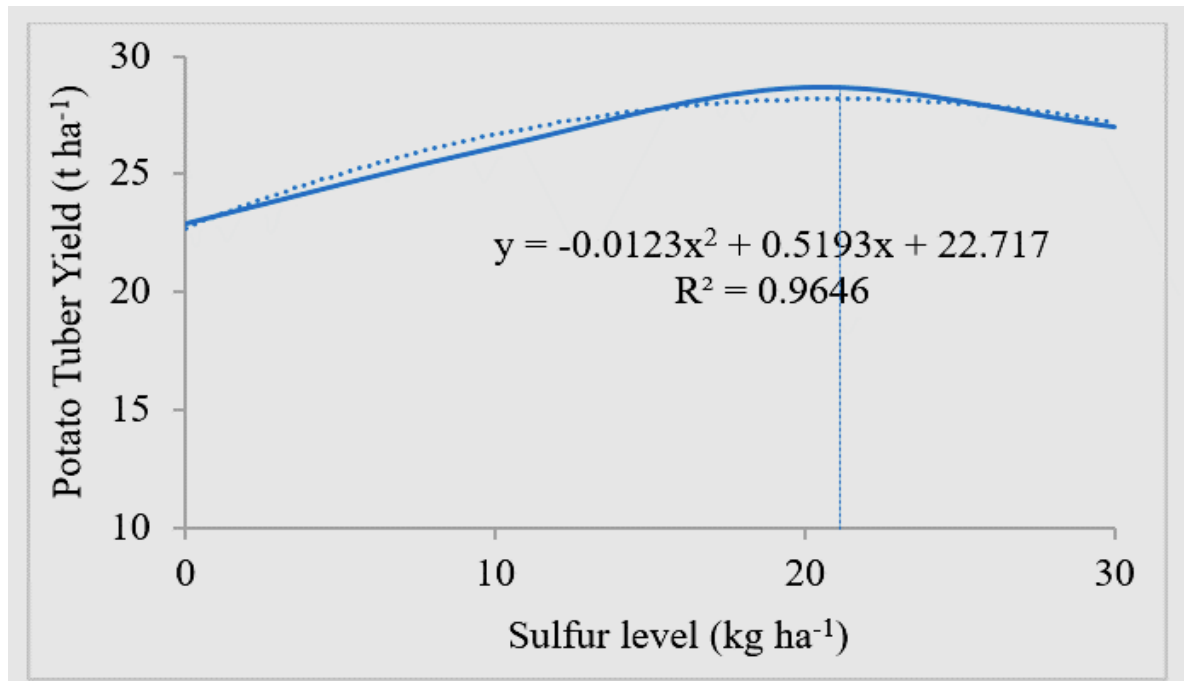

Figure 10. Relationship between sulfur levels with potato tuber yield

Tuber yield tended to decrease with increasing rate of $\mathrm{Mg}$ beyond $10 \mathrm{~kg}$ $\mathrm{ha}^{-1}$. They suggested that maximum tuber yield $\left(30.32\right.$ tha $\left.^{-1}\right)$ could be obtained at $13 \mathrm{~kg} \mathrm{ha}^{-1}$ of Mg. Draycott and Allison (1998) recommended for potato to apply $15-20 \mathrm{~kg} \mathrm{Mg} \mathrm{ha}^{-1}$ to obtain higher tuber yield. The result of present study is very close to their findings. Sharma et al. (2011) showed that sulfur application in potato had significant influence on quality and yield. Highest tuber yield, large size and medium size tuber yield, dry matter content, specific gravity, sugar content and starch content were increased with increasing dose of sulfur. 
Kristufek et al. (2000) observed that control of common scab is mainly caused by different soil amendments and breeding for disease resistance. One of the best methods for combating scab is the use of acid producing fertilizers, especially those that contain liberal amounts of sulfate of ammonia. Hanna et al. (2006) also found that the application of $\mathrm{S}$ can reduce bacterial and fungal diseases in potatoes at the rate of $25 \mathrm{~kg} \mathrm{~S} \mathrm{ha}^{-1}$. Soil characteristics greatly affect by the severity of potato scab in soils with $\mathrm{pH}$ 7. The use of acidifying fertilizers such as ammonium sulfate or diammonium phosphate or applications of sulfur that reduce the soil $\mathrm{pH}$, can induce control of common scab disease (Wiechel and Crump, 2010). The results of present experiment partially support the findings of Kristufek et al. (2000) and Wiechel and Crump (2010). In present experiment, aggregate tuber yields increased quadratically with increasing $\mathrm{Mg}$ application rates up to $15 \mathrm{~kg} \mathrm{Mg} \mathrm{ha-1}$, reaching a plateau thereafter, yield was decreasing at the application of $20 \mathrm{~kg} \mathrm{Mg} \mathrm{ha}$ - $_{1}$. Similar result was found in case of sulfur application rates. Tuber yield increased quadratically with increasing sulfur application rates up to $20 \mathrm{~kg} \mathrm{~S}$ ha $_{-1}$, reaching a plateau thereafter, yield was decreasing at the application of $30 \mathrm{~kg} \mathrm{~S} \mathrm{ha}_{-1}$. Similar results also reported by Talukder et al. (2009); Barczak et al. (2013).

\section{CONCLUSIONS}

The present study revealed that, the incidence of common scab, soft rot and dry rot diseases of seed tuber reduces in application of $\mathrm{Mg}$ and $\mathrm{S}$ at the rate of 15 $\mathrm{kg} \mathrm{Mg} \mathrm{ha}{ }^{-1}$ and $20 \mathrm{~kg} \mathrm{~S} \mathrm{ha}^{-1}$. The higher tuber yield was also obtained from this combination of $\mathrm{Mg}$ and $\mathrm{S}$. However, regression analysis suggested that the maximum yield may obtain at a combination of $\mathrm{Mg}$ and $\mathrm{S}$ at the rates of $15.28 \mathrm{~kg}$ $\mathrm{Mg} \mathrm{ha}^{-1}$ and $21.11 \mathrm{~kg} \mathrm{~S}^{-1}$ to the study area and other similar areas having alluvial soil. Therefore, it is suggested that farmers should apply $15.28 \mathrm{~kg} \mathrm{Mg} \mathrm{ha}^{-1}$ and $21.11 \mathrm{~kg} \mathrm{~S} \mathrm{ha}^{-1}$ along with standard dose of NPK to obtain maximum yield and disease-free seed tuber of potato.

\section{REFERENCES}

Andre, C. M., S. Legay, C. H. Iammarino, J. Ziebel, C. Guignard, Y. Larondelle, J. F. Hausman, D. Evers and L. M. Miranda. 2014. The potato in the human diet: A complex matrix with potential health benefits. Potato Res. 57: 201-214.

Anonymous. 2008. A booklet of production technology of quality seed potato. Tuber Crops Division, BADC (Bangladesh Agricultural Development Corporation), Dhaka, p. 1-8.

Anonymous. 2016. CIP (International Potato Centre), Peru. http://cipotato.org/potato/facts/.

Barczak, B., K. Nowak and T. Knapowski. 2013. Potato yield is affected by sulphur form and rate. Agrochimica. 57(4): 361-369.

Brierley, J., A. Lees and S. Wale. 2008. Powdery Scab-Strains and Conducive Conditions. A review of literature and other sources of information. Agriculture \& Horticulture Development Board (AHDB). Oxford, UK. 
Dobermann, A. and T. Fairhurst. 2000. Economics of fertilizer use. Rice nutrient disorders and nutrient management. Potash and Phosphate Institute. Canada and International Rice Research Institute. Philippines. 38p.

Gomez, K. A. and A. A. Gomez. 1984. Statistical Procedure for agricultural Research. $2^{\text {nd }}$ Edn. International Rice Research Institute. Los Banos, Philippines. John Willy and Sons. New York. 2: 324.

Guo W., H. Nazim, Z. Liang and D. Yang. 2016. Magnesium deficiency in plants: An urgent problem. The Crop J., 4(2): 83-91.

Hanna, K., H. Silvia, B. Elke and S. Ewald. 2006. Influence of sulfur fertilization on infection of potato tubers with Rhizoctonia solani and Streptomyces scabies. J. Plant Nutr. 28(5): 819-833.

Hossain, M., T. K. Dey, M. R. Rahman, A. A. Mahmud and M. M. Rahman. 2004. Integrated management of disease and pest of seed potatoes in Bangladesh. Paper presented in the workshop on present status of seed potato production and its improvement in Bangladesh. Jun 12, 2004. Tuber Crops research Centre, BARI, Gazipur, Bangladesh.

Iqbal, T., M. K. A. Bhuiyan, M. Z. Hoque, A. A. Khan, J. U. Ahmed, M. T.Rubayet. 2019. Chemical and cultural management of common scab (Streptomyces scabies) disease of potato in Bangladesh. Research in: Agricul. \& Vet. Sci. 3(2): 70-83.

Koch, M., M. Naumann, E. Pawelzik, et al. 2020. The importance of nutrient management for potato production Part I: Plant nutrition and yield. Potato Res. 63 (1): 97-119, https://doi.org/10.1007/s11540-019-09431-2.

Kristufek, V., J. Davis, I. Dostalkova and J. Kalcik. 2000. Accumulation of mineral elements in tuber periderm of potato cultivars differing in susceptibility to common scab. Potato Res. 43:107-114.

Marcomini, G. R., M. T. O. Patino, M. J. Alam, and F. R. de Amorim. 2019. Lessons from a cost's analysis in potato production. Emir. J. Food Agric. 31 (11): 857-63, doi: https://doi.org/10.9755/ejfa.2019.

Rubayet, M. T., M. K. A. Bhuiyan and M. M. Hossain, 2017. Effect of soil solarization and biofumigation on stem rot disease of potato caused by Sclerotium rolfsii. Ann. Bangladesh Agric. 21 (1 \& 2): 49-59.

Sharma, D. K., S. S. Kushwah, P. K. Nema and S. S. Rathore. 2011. Effect of sulphur on yield and quality of potato (Solanum tuberosum L.). Intern. J. Agric. Res. 6: 143-148.

Software, A. (2020). Statistix - Home. https://www.statistix.com/

Talukder, M. A. H., M. B. Islam, S. M. A. H. M. Kamal, M. A. Mannaf and M. M. Uddin. 2009. Effects of magnesium on the performance of potato in the tista meander floodplain soil. Bangladesh J. Agril. Res. 34(2): 255-261.

Wiechel, T. J. and N. S. Crump. 2010. Soil nutrition and common scab disease of potato in Australia. World Congress of Soil Science, Soil Solution for a Changing World. Brisbane, Australia, Published on DVD. 